\section{Cold Injury of Peach and Nectarine Cultivars after a Fall Freeze}

\author{
Michael W. Smith'and Becky L. Carroll ${ }^{2}$ \\ Department of Horticulture and Landscape Architecture, Oklahoma State \\ University, Stillwater, OK 74078
}

\author{
Glenn G. Taylor ${ }^{3}$ \\ The Samuel Roberts Noble Foundation, Ardmore, OK 73402
}

Additional index words. Prunus persica, cold damage, winter injury

Cold damage to peach [Prunus persica $(\mathrm{L}$. Batsch.] trees occurs in many of the peachgrowing regions and can result in tree death or predispose trees to canker caused by Pseudomonas (Yadava and Doud, 1989) or Leucostoma (Chang et al., 1989). Cold damage also can contribute to the peach tree shortlife complex (Nesmith and Dowler, 1976; Savage, 1970). Layne (1992) has recently reviewed available literature concerning peach and nectarine cold hardiness.

Information that compares cold injury sustained by peach or nectarine cultivars during a test winter is lacking. The opportunity to collect these data only occurs when uniform plantings of diverse cultivars are exposed to test winters. Such information is valuable for cultivar recommendations and to identify coldhardy cultivars for use in breeding programs. This note reports data collected after a severe freeze on 2 Nov. 1991.

Temperatures dropped from 5 to $-11 \mathrm{C}$ within $12 \mathrm{~h}$ at the Fruit Research Station near Perkins in central Oklahoma. There had not been prior freezing temperatures, and trees were fully foliated. Four-year-old peach and nectarine cultivars propagated on Lovell rootstock and trained to an open center were rated on 25 Sept. 1992 for cold injury. Trees were not pruned after exposure to injurious low temperatures. Tree damage was quantified on a rating scale for injury: $1=$ none; $2=$ crotch areas; $3=$ the crotch areas and trunk, $4=$ the crotch areas, trunk, and lower portions of the scaffolds; $.5=$ injury to the crotch areas, trunk, and scaffolds, with trunk splitting, poor shoot growth, and yellow foliage; and $6=$ death of the aboveground portion of the tree (rootstock may be suckering). There were four to five trees of each cultivar. Data were tested using analysis of variance with the protected LSD.

The soil was a Teller loam (fine-loamy,

Received for publication 12 Oct. 1993. Accepted for publication 15 Jan. 1994. Research funded by the Oklahoma Agricultural Experiment Station. Approved by the Director of the Oklahoma Agricultural Experiment Station. The cost of publishing this paper was defrayed in part by the payment of page charges. Under postal regulations, this paper therefore must be hereby marked advertisement solely to indicate this fact.

'Professor.

'Research Technician.

${ }^{3}$ Horticulturist. mixed, thermic, Udic Argiustolls; Mollisols) with a $1 \%$ slope. Orchard management included closely mowed sod with 1-m-wide, weed-free strips on each side of the tree using recommended herbicides, watering by trickle irrigation, fertilizing based on leaf analysis, and controlling pests following Oklahoma State Univ. extension service recommendations. Trees were healthy when exposed to the freeze.

'Fantasia' and 'Sunfre' nectarine had the least cold injury, and 'Armking', 'Mayfire', and 'Sungem' were killed by the fall freeze (Fig. 1). The other nectarine cultivars were intermediate in cold injury.

One peach cultivar, 'Sentinel', had less damage (1.8 rating) than other cultivars evaluated (Fig. 2), indicating that the fall freeze had little impact on this cultivar, and subsequent canker infections were not likely. 'Sam Houston' was the only peach cultivar with all trees killed. Cold injury of the other cultivars ranged from ratings of 3 to 5 .

\section{Literature Cited}

Chang, L.S., A. Iezzoni, G. Adams, and G.S. Howell. 1989. Leucostoma persoonii tolerance and cold hardiness among diverse peach genotypes. J. Amer. Soc. Hort. Sci. 114:482-485.

Layne, R.E.C. 1992. Breeding cold hardy peaches and nectarines, p. 271-308. In: J. Janick (ed.). Plant breeding reviews, vol. 10. Wiley, New York.

Savage, E. 1970. Cold injury as related to cultural management and possible protective devices for dormant peach trees. HortScience 5:425-428.

Yadava, U.L. and S.L. Doud. 1989. Rootstock and scion influence growth, productivity, survival, and short life-related performance of peach trees. J. Amer. Soc. Hort. Sci. 114:875-880.

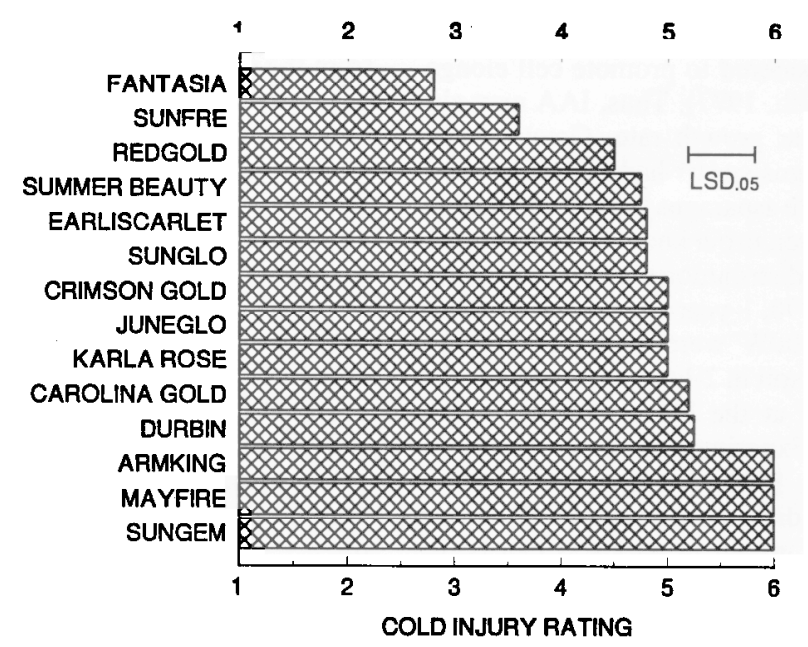

Fig. 1. Cold injury ratings of 4 - year-old nectarine cultivars following an early fall freeze to -11C. Damage rating was from 1 (no visible injury) to 6 (death of the aboveground portion of the tree

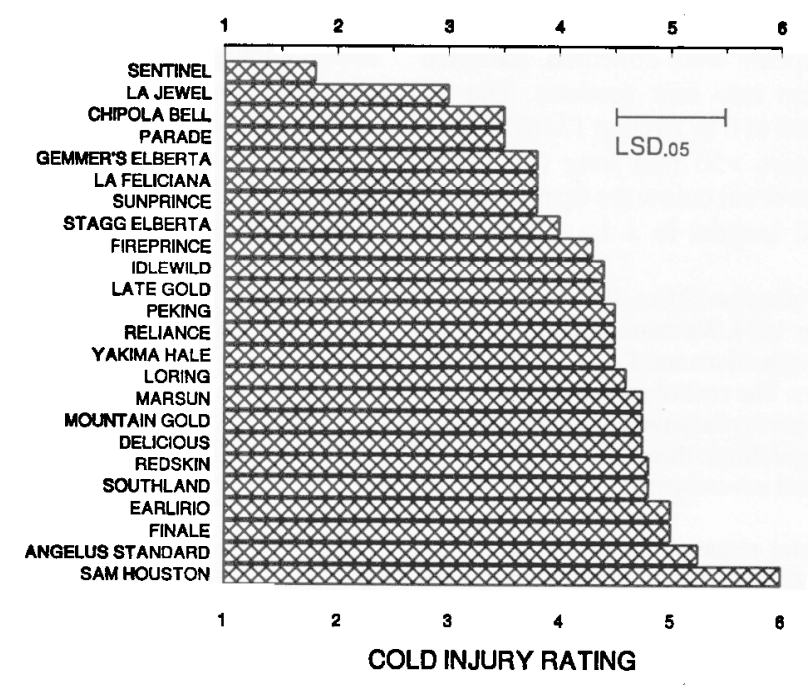

Fig. 2. Cold injury ratings of 4-year-old peach cultivars following an early fall freeze to -11C. Damage rating was from 1 (no visible injury) to 6 (death of the aboveground portion of the tree). 